\title{
Ligand-induced endocytosis and nuclear localization of angiotensin II receptors expressed in CHO cells
}

\author{
A.J. Merjan ${ }^{1}$, \\ C.A. Kanashiro ${ }^{1}$, \\ J.E. Krieger' ${ }^{2}$ S.W. Han ${ }^{1}$ \\ and A.C.M. Paiva ${ }^{1}$
}

\author{
'Departamento de Biofísica, Escola Paulista de Medicina, \\ Universidade Federal de São Paulo, São Paulo, SP, Brasil \\ ${ }^{2}$ Laboratório de Biologia Molecular, Instituto do Coração, \\ Faculdade de Medicina, Universidade de São Paulo, São Paulo, SP, Brasil
}

\author{
Correspondence \\ A.C.M. Paiva \\ Departamento de Biofísica \\ EPM, UNIFESP \\ Rua Botucatu, 862 \\ 04023-062 São Paulo, SP \\ Brasil \\ Fax: + 55-11-571-5780 \\ E-mail: acmpaiva@biofis.epm.br \\ Research supported by FAPESP \\ and $\mathrm{CNPq}$.
}

Received October 31, 2000

Accepted June 12, 2001

\section{Abstract}

A construct (AT1R-NF) containing a "Flag" sequence added to the Nterminus of the rat $\mathrm{AT}_{1}$ receptor was stably expressed in Chinese hamster ovary cells and quantified in the cell membrane by confocal microscopy after reaction with a fluorescein-labeled anti-Flag monoclonal antibody. Angiotensin II bound to AT1R-NF and induced endocytosis with a half-time of $2 \mathrm{~min}$. After 60-90 min, fluorescence accumulated around the cell nucleus, suggesting migration of the ligand-receptor complex to the nuclear membrane. Angiotensin antagonists also induced endocytosis, suggesting that a common step in the transduction signal mechanism occurring after ligand binding may be responsible for the ligand-receptor complex internalization.

\section{Key words}

- Angiotensin II

- Agonist-induced receptor internalization

- Endocytosis

- Fluorescence-tagged receptor

- Nuclear angiotensin receptors

- Renin-angiotensin system

\section{Introduction}

Two receptor subtypes $\left(\mathrm{AT}_{1}\right.$ and $\left.\mathrm{AT}_{2}\right)$ have been described for the octapeptide hormone angiotensin II, the $\mathrm{AT}_{1}$ receptor being responsible for most of the classical actions of this peptide (for a review, see Ref. 1).

As is the case with other $G$ proteincoupled receptors, interaction of the $\mathrm{AT}_{1}$ receptor with its specific ligand, besides triggering the release of second messengers that leads to cellular responses (2), also triggers endocytosis (for a review, see Ref. 3) and processing of the ligand-receptor complex which occurs in endosomes, part of the receptors being returned to the plasma membrane (4). Internalization and recycling are important factors in determining the number of free receptors on the cell surface available for interaction with the ligand (5).

The structural requirements for ligandinduced internalization of $\mathrm{G}$ protein-coupled receptors have been investigated, and different motifs were found to be involved in this process. Usually these motifs are located in the intracellular domains of the receptors and contain aromatic (mainly tyrosine) or hydrophobic amino acid residues. One such motif is the highly conserved NPXXY sequence located in the intracellular end of the seventh transmembrane domain, containing a tyrosine residue that was shown to be essential for internalization of the $\beta_{2}$-adrenergic receptor (6). However, mutations in the corresponding motif in the angiotensin $\mathrm{AT}_{1}$ receptor did not affect ligand-induced internalization (7-9). On the other hand, the Cterminal cytoplasmic domain of $\mathrm{AT}_{1}$ was 
found to be important for internalization (8, 10,11), particularly residues L316, Y319 (6), T332, S335, T336 and L337 (7). Furthermore, residues 215-220 at the N-terminal portion of the third intracellular loop, but not other segments of this loop, were found to be important for $\mathrm{AT}_{1}$ endocytosis (12).

Since $\mathrm{AT}_{1}$ ligand-induced internalization is independent of the triggering of the cellular responses by angiotensin II, it is possible that the structural features responsible for agonist-receptor internalization may differ from those involved in binding and signal transduction. In this respect, the available data are somewhat conflicting. Conchon et al. (13) report that the agonist [Sar $\left.{ }^{1}\right]$-angiotensin II and the antagonist $\left[\mathrm{Sar}^{1}, \mathrm{Ile}^{8}\right]$-angiotensin II are equally potent in inducing internalization of $\mathrm{AT}_{1}$ receptors, whereas the nonpeptide antagonist DuP735 is far less potent. Other authors, however, found that peptide antagonists are much less capable (14) or incapable (15) of promoting receptor internalization. These findings, however, were obtained with radio-iodinated ligands, and it would be important to compare them with measurements made with non-iodinated ligands. Furthermore, previous studies of internalization were done with the "acid wash" technique, in which the amount of internalized radiolabeled ligand is estimated by the amount of radioactivity that remains on the cell after treatment with an acidic solution, which is thought to selectively remove non-internalized ligand. It would be desirable to investigate this phenomenon with a more direct method for the assessment of receptor internalization. Therefore, in the present study we have examined the ability of non-iodinated agonists and antagonists to induce internalization of wild-type rat $\mathrm{AT}_{1 \mathrm{~A}}$ receptors stably expressed in Chinese hamster ovary (CHO-K1) cells. To estimate internalization we used a method based on the introduction of an epitope ("Flag") at the amino terminus of the receptor, and detection of the Flag-tagged receptor (AT1R-NF) in the cells by immunofluorescence and confocal microscopy.

\section{Material and Methods}

\section{Ligands}

Angiotensin II, [Sar ${ }^{1}$-angiotensin II and $\left[\mathrm{Sar}^{1}, \mathrm{Ala}^{8}\right]$-angiotensin II were synthesized by the solid phase method using Boc-chemistry, as previously described (16). The peptides were purified by HPLC and their purity and molecular weight were confirmed by mass spectrometry. DuP753 was kindly provided by the DuPont Merck Pharmaceutical Co. (Wilmington, DE, USA). Angiotensin II was labeled in our laboratory with ${ }^{125} \mathrm{I}$ (2200 $\mathrm{Ci} / \mathrm{mmol}$ ) (Amersham, Little Chalfont, Buckinghamshire, UK) using the iodo-beads method (Pierce Chemical Co., Rockford, IL, USA), as previously described (17).

\section{Construction of pAT1R-NF}

A vector coding for a construct containing the Flag epitope (DYLDDDDL) added to the $\mathrm{N}$-terminus of the rat $\mathrm{AT}_{1 \mathrm{~A}}$ receptor (18) was generated. Initially, the $\mathrm{AT}_{1} \mathrm{cDNA}$ was cut from the p171 vector (19) by hydrolysis with the restriction enzymes $N c o$ I and BamHI. The vector pGEM3z-FlagßH6 (containing the sequence: signal peptide-endopeptidase cleavage site-Flag-ß-adrenergic receptor) was also hydrolyzed by the same restriction enzymes to remove the adrenergic receptor sequence and the $\mathrm{AT}_{1}$ cDNA was inserted and ligated in its place. The resulting vector was hydrolyzed with BamHI and HindIII to release Flag-AT1R and placed in $\mathrm{p} 171$ at the same restriction sites. The final construct, named pAT1R-NF, contains the $\mathrm{AT}_{1}$ receptor sequence with the addition of the octapeptide Flag sequence at the Nterminus.

\section{Transfection of pAT1R-NF into CHO-K1 cells}

The cells were seeded at the density of 
$10^{4}$ cells $/ \mathrm{cm}^{2}$ in $80-\mathrm{cm}^{2}$ culture bottles (Corning Costar Corp., Cambridge, MA, USA) and maintained in RPMI medium (Gibco BRL, Gaithersburg, MD, USA) containing $10 \%$ fetal calf serum, $2 \mathrm{mM}$ glutamine, 100 $\mathrm{U} / \mathrm{ml}$ penicillin and $100 \mu \mathrm{g} / \mathrm{ml}$ streptomycin at $37^{\circ} \mathrm{C}$ with $5 \% \mathrm{CO}_{2}$ and $95 \%$ air. After $24 \mathrm{~h}$ the cells were transfected with $20 \mu \mathrm{g}$ DNA by co-precipitation with calcium phosphate (20), and $48 \mathrm{~h}$ later were submitted to antibiotic selection with $0.8 \mathrm{mg} / \mathrm{ml} \mathrm{G}-418$ (Gibco). The selection process was maintained for about 2 weeks, until antibiotic-resistant clones were obtained. To isolate the clones, the cells were trypsinized and diluted to a single cell per well on a 96-well plate. The cells were maintained under the same conditions and, as confluence was attained, they were successively transferred to 24- and 6well plates.

\section{Northern blot assays}

The cells were cultured in $80-\mathrm{cm}^{2}$ culture bottles until confluence was reached. Total RNA was extracted by lysis of the confluent cells with Trizol solution (Gibco), and purified under the conditions and according to the procedures recommended by the manufacturer. After electrophoresis on agarose gel with $1.2 \%$ formaldehyde (20), the RNA was transferred from the gel to a nylon membrane (Bio-Rad Laboratories, Hercules, CA, USA) by capillarity for $6 \mathrm{~h}$, with salinesodium citrate buffer (Sigma, St. Louis, MO, USA). Hybridization was done at $42^{\circ} \mathrm{C}$ under the conditions suggested by the membrane manufacturer, using as probes the $\mathrm{AT}_{1}$ receptor cDNA or the region corresponding to the Flag sequence labeled with ${ }^{32} \mathrm{P}-\mathrm{dCTP}$ (Amersham). The time for autoradiography varied from 3 to 4 days at $-80^{\circ} \mathrm{C}$ with an intensifying screen.

\section{Immunocytochemistry}

Transfected cells grown on coverslips were rinsed in $100 \mathrm{mM}$ PBS, $\mathrm{pH} 7.4$, and then incubated in RPMI medium without serum (Gibco) at $37^{\circ} \mathrm{C}$ for $30 \mathrm{~min}$. Ligands were added to the cells and incubated for specific time periods in the humidified incubator. The cells were washed twice with 0.5 $\mathrm{ml}$ PBS and incubated with $1 \%$ BSA in PBS at $37^{\circ} \mathrm{C}$ for $30 \mathrm{~min}$ to block nonspecific binding. Two different procedures were used to visualize the receptors by immunofluorescence. To detect the receptors present only on the cell surface, the ligand-treated cells were first incubated with $10 \mu \mathrm{g} / \mathrm{ml}$ of primary antibody (mouse anti-Flag M2 monoclonal antibody, Eastman Kodak Co., Rochester, NY, USA) for $30 \mathrm{~min}$ at room temperature. The cells were washed with $0.5 \mathrm{ml}$ PBS and incubated with the secondary antibody, rabbit anti-mouse IgG labeled with fluorescein isothiocyanate (FITC) (Sigma), and left for $30 \mathrm{~min}$ at room temperature. The coverslips were washed and the cells fixed with methanol for $3 \mathrm{~min}$ and then mounted in glycerol-buffered PBS (1:9). To reveal intracellularly located receptors as well, the fixation step preceded the treatment with the primary and secondary antibodies. Previous fixation using methanol allowed the antibody to reach the intracellular compartment, a fact that did not occur in the post-fixed cells. The cells were examined with a BioRad 1024-UV confocal system attached to a Zeiss Axiovert 100 microscope, using a $63 \mathrm{x}$ NA 1.4-Plan-Apochromatic (DIC) oil immersion objective and a 2-mm pinhole. Kalman averaging was used to collect all images. The fluorescent images were printed using an NP-1600 printer from Codonics. After localizing an area with homogeneously spread cells, the fluorescence contained on a defined surface was measured using the Quant Laser Sharp software, version 1.02 (Bio-Rad). With this program it is possible to eliminate the background and quantify the fluorescence emitted by cells. For each experiment, repeated four times, the measurements were made with the same number of 
Figure 1. Northern blot of total RNA extracted from CHO-K1 cells. Lanes 1 and 4, Nontransfected cells; lanes 2 and 5 , cells transfected with AT1R-NF; lanes 3 and 6, cells transfected with the wild-type receptor. Blots were probed with a ${ }^{32} \mathrm{P}$-labeled oligonucleotide complementary to the Flag sequence (lanes 1, 2 and 3 ) or with full-length wildtype cDNA (lanes 4, 5 and 6). The positions of $28 \mathrm{~S}$ and $18 \mathrm{~S}$ ribosomal RNA are indicated.

Figure 2. Competition binding of angiotensin II to $\mathrm{CHO}-\mathrm{KI}$ cells stably expressing AT1R-NF and wild-type receptors. The cells were incubated overnight with 30 pM [ [25/]-angiotensin II ([ ${ }^{125}$ ] Ang II) at $4^{\circ} \mathrm{C}$ in the presence of different concentrations of unlabeled angiotensin II. Each point represents the mean \pm SD from 6-9 determinations. cells (100). In cells treated with different ligand concentrations, the rate of internalization was estimated by the disappearance of the fluorescence associated with the membranes. Groups of cells not treated with the ligand, in which the fluorescence was restricted to the cell membranes, were used as controls for internalization.

\section{Receptor internalization}

Agonist-induced receptor endocytosis was estimated by measuring the disappearance of the AT1R-NF receptor from the cell membrane, as visualized by immunocytochemistry, and also by the "acid wash" method, which is commonly used to distinguish between cell surface and intracellular receptors (21). The cells were incubated with $100 \mathrm{nM}$ angiotensin II for different times and incubations were stopped by washing with PBS. The cells were washed for $3 \mathrm{~min}$ with $50 \mathrm{mM}$ acetic acid in $150 \mathrm{mM} \mathrm{NaCl}, \mathrm{pH} 3.0$, followed by two washes with PBS. The cells were incubated with BSA, and then with the primary and secondary anti-
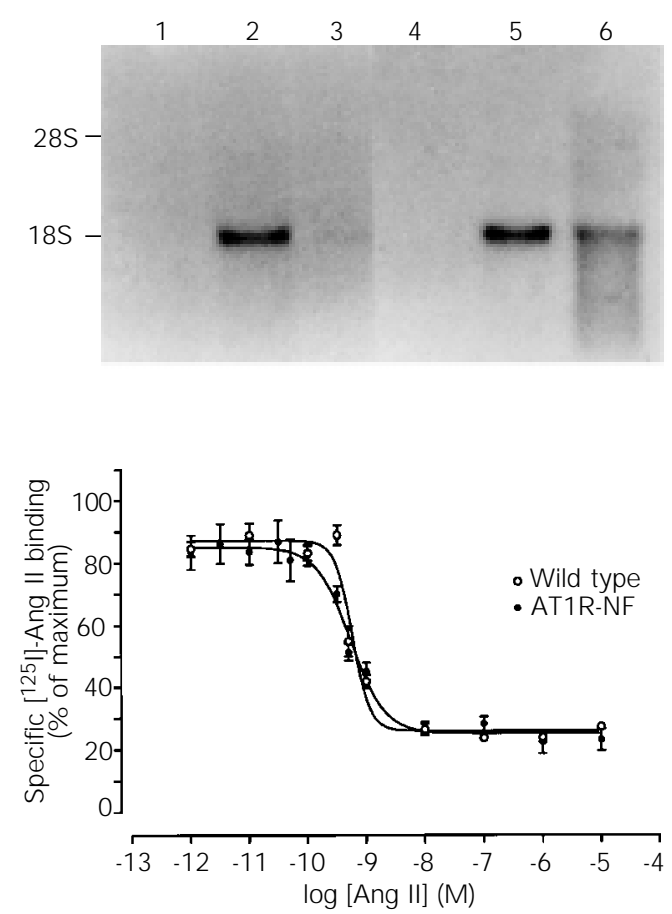

bodies, post-fixed with methanol and examined for fluorescence as described above.

\section{Binding experiments}

CHO-K1 cells transfected with pAT1RNF were seeded at $5 \times 10^{4}$ cells per well in 24-well plates, and left for $24 \mathrm{~h}$ at $37^{\circ} \mathrm{C}$ in a humidified incubator with $5 \% \mathrm{CO}_{2}$ and $95 \%$ air. The culture medium was siphoned off and the cells were washed twice with cold PBS and then incubated in "binding buffer" (50 mM Tris- $\mathrm{HCl}, \mathrm{pH} 7.5,120 \mathrm{mM} \mathrm{NaCl}, 4$ $\mathrm{mM} \mathrm{KCl}, 5 \mathrm{mM} \mathrm{MgCl} 2,1 \mathrm{mM} \mathrm{CaCl} 2,10 \mu \mathrm{g} /$ $\mathrm{ml}$ bacitracin and $2 \mathrm{mg} / \mathrm{ml}$ glucose) in the presence of $30 \mathrm{pM}\left[{ }^{125} \mathrm{I}\right]$-angiotensin II and of different concentrations of unlabeled angiotensin II ( $1 \mathrm{pM}$ to $10 \mu \mathrm{M})$. After overnight incubation at $4{ }^{\circ} \mathrm{C}$ with gentle shaking, the binding buffer was siphoned off, the cells were washed three times with "washing buffer" ( $25 \mathrm{mM}$ Tris-HCl, $140 \mathrm{mM} \mathrm{NaCl}, 5$ $\mathrm{mM} \mathrm{MgCl} 2,0.1 \%$ BSA) and then lysed with $2 \% \mathrm{NP}-40$ solution containing $8 \mathrm{M}$ urea and $3 \mathrm{M}$ acetic acid. Receptor-bound radiolabel was counted with a gamma counter (Packard) and the results were treated by nonlinear regression analysis using the "GraphPad Prism" (Graph-Pad Software, San Diego, CA, USA) to determine the kinetic constants.

\section{Results}

\section{Characterization of the ATIR-NF receptor expressed in $\mathrm{CHO}-\mathrm{K} 1$ cells}

The expression of the $\mathrm{AT}_{1}$ receptor, alone or linked with the Flag epitope, was analyzed by Northern blot using total RNA extracted from stably transfected $\mathrm{CHO}-\mathrm{K} 1$ cells. Figure 1 shows that the untransfected cells expressed undetectable levels of $\mathrm{AT}_{1}$ receptor mRNA, whereas those transfected with AT1R-NF showed a positive signal with both probes of a size corresponding to about $18 \mathrm{~S}$ ribosomal RNA. When a ${ }^{32} \mathrm{P}$-labeled oligonucleotide complementary to the Flag 
sequence was used as a probe, only cells transfected with AT1R-NF showed the corresponding band, confirming the presence of the Flag label in the receptor.

Figure 2 shows that the ligand-binding properties of the $\mathrm{CHO}-\mathrm{K} 1$ cells expressing the Flag-labeled receptor were similar to those of the wild-type $\mathrm{AT}_{1}$, with $\mathrm{EC}_{50}$ values of $6.2 \mathrm{nM}$ and $5.8 \mathrm{nM}$, respectively.

\section{Immunocytochemistry}

In cells expressing the AT1R-NF mutant, strong fluorescence signals were observed after treatment with $100 \mathrm{nM}$ angiotensin II and incubation with the anti-Flag antibody at room temperature. When incubation with the antibody preceded fixation, a strong fluorescence was observed on the cell surface (Figure 3A), which gradually disappeared at $37^{\circ} \mathrm{C}$ (Figure 3B-D). When incubation was performed at $4{ }^{\circ} \mathrm{C}$, the fluorescence remained on the cell surface after $90 \mathrm{~min}$ (Figure 3E). When the antibody was applied to angiotensin II-treated cells after fixation with methanol, the fluorescence initially appeared on the cell surface (Figure 4A), and then gradually moved to the intracellular space (Figure 4B-F). At the end of the 90-min observation period, all fluorescence had disappeared from the cell surface and tended to be distributed around the cell nuclei (Figure 4F). In nontransformed $\mathrm{CHO}$ cells and in cells transfected with wild-type $\mathrm{AT}_{1}$ receptors no fluorescence was observed after up to 90 -min incubation using either protocol (data not shown).

A half-time of internalization of $2 \mathrm{~min}$ was found, which was confirmed by the acid

Figure 3. Agonist-induced AT1R-NF internalization visualized by reaction with the anti-Flag $\mathrm{M} 2$ antibody before fixation with methanol. CHO-K1 cells expressing the AT1R-NF receptor were incubated with $100 \mathrm{nM}$ angiotensin II at $37^{\circ} \mathrm{C}$ for 0 (A), 10 (B), 30 (C) and 90 (D) min or at $4^{\circ} \mathrm{C}$ for $24 \mathrm{~h}(\mathrm{E})$. The cells' immunofluorescence is shown on the left and the respective no-mask images are shown on the right.
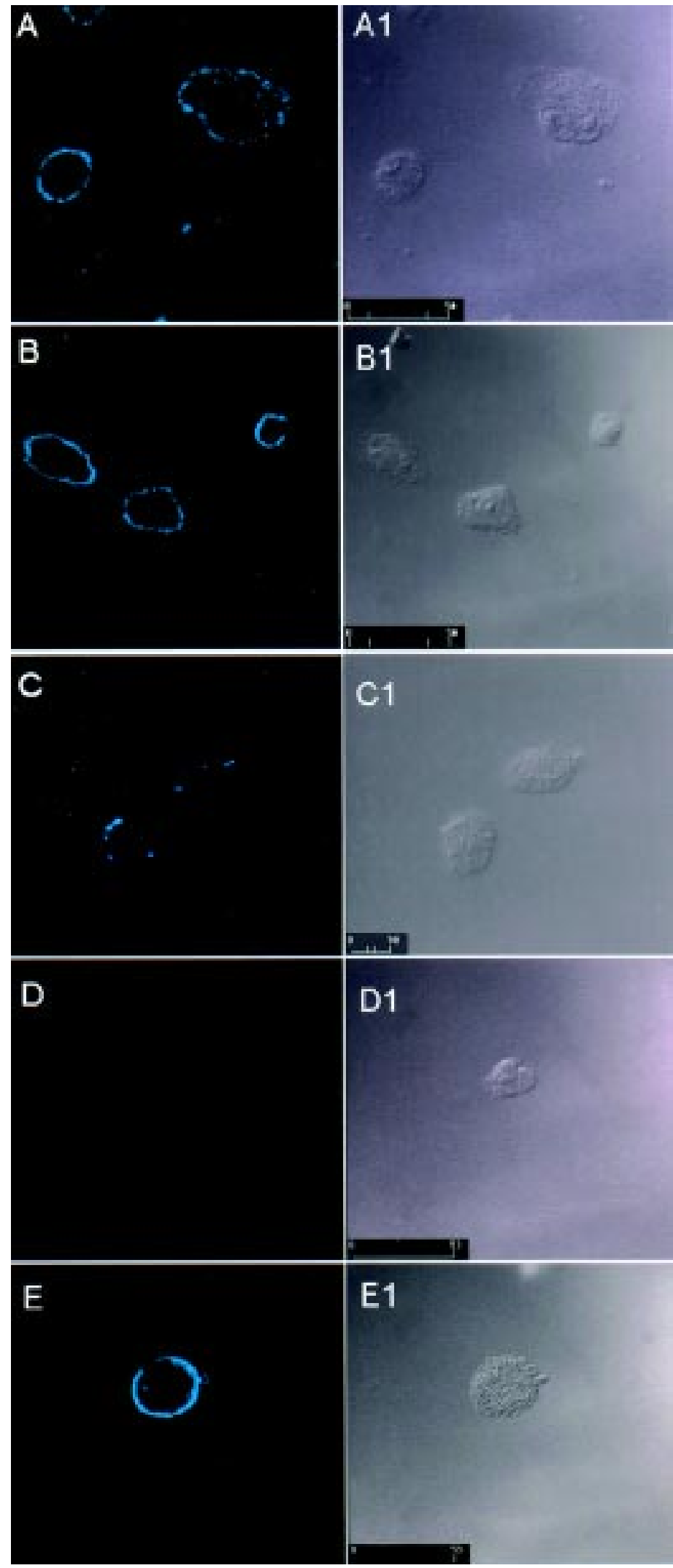


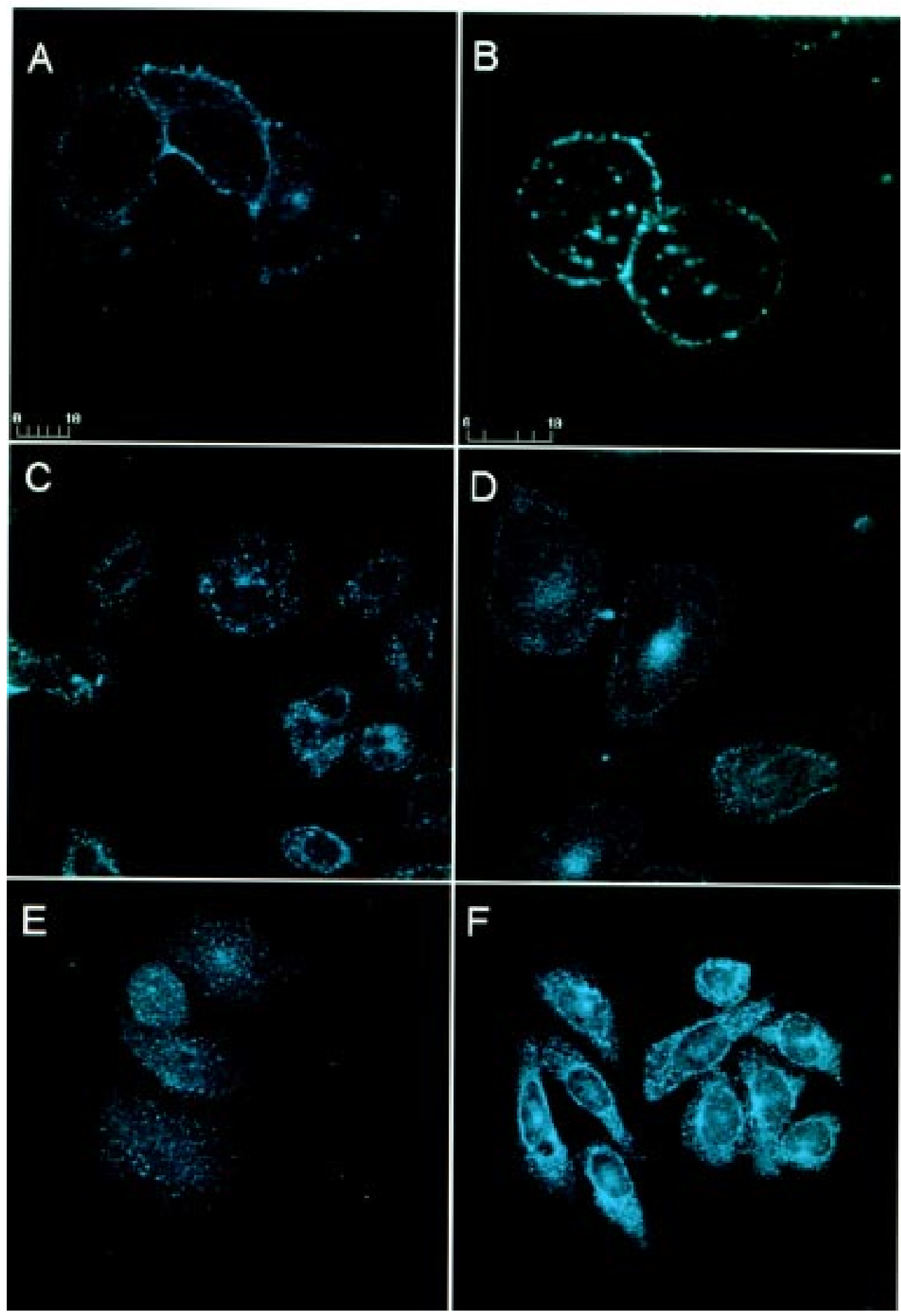

Figure 4. Agonist-induced ATIR-NF internalization visualized by reaction with the anti-Flag M2 antibody after fixation with methanol. CHO-K1 cells expressing the AT1R-NF receptor were incubated with $100 \mathrm{nM}$ angiotensin II at $37^{\circ} \mathrm{C}$ for $0(\mathrm{~A}), 10(\mathrm{~B}), 20(\mathrm{C}), 40(\mathrm{D}), 60(\mathrm{E})$ and $90(\mathrm{~F}) \mathrm{min}$. 
wash method (data not shown) and was similar to the values described in the literature for angiotensin endocytosis in different cells (21). Figure 5 shows that angiotensin II induced internalization of the AT1R-NF receptor with an $\mathrm{EC}_{50}$ of $2 \mathrm{nM}$, which is close to the $6.2 \mathrm{nM}$ value obtained in the binding experiments (Figure 2). Similar results were obtained with other ligands, namely the agonistic peptide analogue [Sar ${ }^{1}$-angiotensin II and the antagonistic peptide analogue $\left[\mathrm{Sar}^{1}, \mathrm{Ala}^{8}\right]$-angiotensin II, whereas the nonpeptide antagonist DuP753 was internalized with about $50 \%$ of the degree of endocytosis observed with angiotensin II. As a control we employed bradykinin, a peptide that does not interact with angiotensin II receptors and was not internalized.

Staurosporine, an inhibitor of protein kinases $\mathrm{C}$ and $\mathrm{A}$, which is thought to inhibit receptor desensitization (22), had no significant effect on the internalization induced by high angiotensin II concentrations (Figure 5).

\section{Discussion}

Our results show that $\mathrm{CHO}-\mathrm{K} 1$ cells stably transfected with the Flag-tagged angiotensin II receptor bind angiotensin II with an affinity similar to that of cells expressing the wild-type $\mathrm{AT}_{1}$, confirming that the modified receptor is properly expressed in the cell membrane (3).

We have demonstrated that the expression of the AT1R-NF receptor in the cell membrane may be quantitatively determined by integration of the fluorescence signal associated with the membrane after treatment with the mouse anti-Flag antibody followed by the fluorescent-labeled rabbit anti-mouse IgG. This quantitation of the receptors present on the cell membrane allows a more direct procedure to measure angiotensin II receptor endocytosis. The internalization was specific for $\mathrm{AT}_{1}$ receptor ligands, since it was not observed with bradykinin, which does not bind to angiotensin II receptors. In

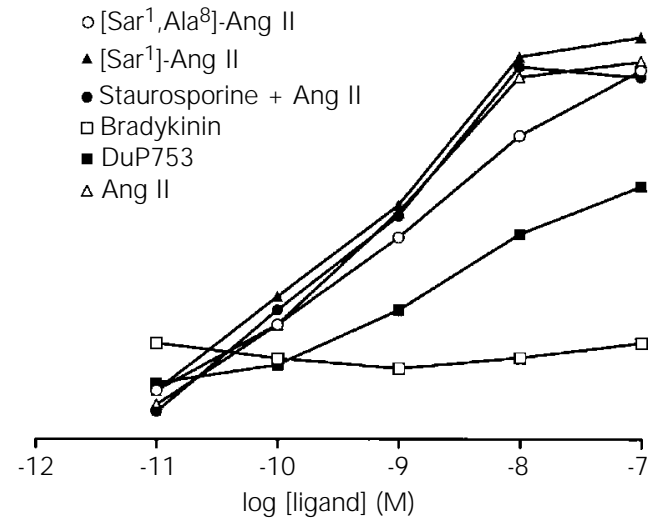

addition, the protein kinase inhibitor staurosporine did not prevent internalization, in agreement with the hypothesis that desensitization is caused by the rapid uncoupling of the receptor from $G$ protein and not necessarily by receptor internalization $(22,23)$.

Although less is known about the sites of the extracellular domains of $\mathrm{AT}_{1}$ that are important for triggering receptor internalization, some information may be inferred from ligand structure-activity studies. The peptide analogue [Sar $\left.{ }^{1}\right]$-angiotensin II, which has a high agonistic activity (24), and the peptide antagonist $\left[\mathrm{Sar}^{1}, \mathrm{Ala}^{8}\right]$-angiotensin II both caused internalization with the same efficiency as angiotensin II (Figure 5). This is in agreement with the previous finding that $\left[\mathrm{Sar}^{1}\right]$-angiotensin II and $\left[\mathrm{Sar}^{1}, \mathrm{Ile}^{8}\right]$-angiotensin II are equally capable of promoting receptor internalization in $\mathrm{CHO}$ cells expressing $\mathrm{AT}_{1}$ (13), but contrasts with reports that angiotensin II antagonists are less capable (14) or incapable (25) to induce endocytosis in cultured adrenal glomerulosa cells.

It is noteworthy that even the nonpeptide antagonist DuP753 was able to induce endocytosis, albeit with less efficiency than the peptide analogues, also in agreement with previous findings with transfected $\mathrm{CHO}$ cells (14). Since previous work has shown that different receptor sites are responsible for binding peptide and nonpeptide ligands
Figure 5. Effect of different ligands on the rate of angiotensin II (Ang II) receptor internalization. The $\mathrm{CHO}-\mathrm{K} 1$ cells expressing the ATIR-NF receptor were incubated with different concentrations of the ligands at $37^{\circ} \mathrm{C}$ for $30 \mathrm{~min}$ and fixed with methanol after labeling with the anti-Flag/FITC-anti-mouse IgG system. The fluorescence signal associated with the cell membrane was integrated and expressed as a percentage of the fluorescence emitted by cells incubated in the absence of ligand. 
$(26,27)$, the fact that both types of ligands cause internalization suggests that a common step in the transduction chain of events occurring after binding may be responsible for ligand-induced endocytosis. Further studies are needed to investigate this possibility and to characterize this hypothetical step.

Receptor-mediated sequestration and endocytosis have been shown to be the first steps in receptor processing and recycling, involving capture of both ligand and receptor by endosomes, followed by diversion of angiotensin II to lysosomes and recycling of the receptors to the plasma membrane (4). In our experiments, however, we detected an accumulation of immunofluorescence around the cell nuclei, indicating that part of the receptor molecules are able to reach the nucleus, possibly bound to their specific ligand.

Some evidence has been reported that angiotensin II, besides its better known effect on plasma membrane receptors triggering second-messenger cascades, may be transported to the nucleus, where it may interact directly with receptors on the nuclear membrane. Thus, early autoradiographic experiments (28) showed that tritium-labeled angiotensin II accumulated around the nuclei of smooth and cardiac muscle cells, and more recent work showed that an angiotensin II-colloidal gold conjugate also tended to locate around the nuclei (29). Furthermore, high-affinity specific angiotensin II receptors of type I were shown to be present in the nuclear membrane and to induce transcription of renin and angiotensinogen RNA $(30,31)$.

A high-affinity soluble angiotensin IIbinding protein has been described in the cytosol of liver cells (32), which may play a role in transporting angiotensin II molecules from the cell membrane to the perinuclear space where it may interact with nuclear membrane receptors. Another possibility, however, suggested by our results, is that the $\mathrm{AT}_{1}$ receptor itself, through ligand-induced internalization, may transport the hormone to the nucleus, where it might deliver it to the nuclear receptors.

\section{Acknowledgments}

We are grateful to Prof. Renato A. Mortara, Department of Parasitology, Federal University of São Paulo, for help and guidance with the confocal microscope experiments, and to Prof. Thue W. Schwartz, Panun Institute, University of Copenhagen, for the gift of the p171 vector plasmid.

\section{References}

1. Gasparo $M$, Catt $\mathrm{KJ}$, Inagami $\mathrm{T}$, Wright J W \& Unger Th (2000). International Union of Pharmacology. XXIII. The angiotensin II receptors. Pharmacological Reviews, 52: 415-472.

2. Han HMCB, Shimuta SI, Kanashiro CA, Oliveira L, Han SW \& Paiva ACM (1998). Residues Val254, His 256 and $\mathrm{Phe}^{259}$ of the angiotensin II AT1 receptor are not involved in ligand binding but participate in signal transduction. Molecular Endocrinology, 12: 810-814.

3. Hunyady L, Catt KJ , Clark AJ L \& Gáborik Z (2000). Mechanisms and functions of $A T_{1}$ angiotensin receptor internalization. Regulatory Peptides, 91: 29-44.

4. Hein L, Meinel L, Pratt RE, Dzau VJ \&
Kobilka BK (1997). Intracellular trafficking of angiotensin II and its $A T_{1}$ and $A T_{2}$ receptors: evidence for selective sorting of receptor and ligand. Endocrinology, 11: 1266-1277.

5. Ullian ME \& Linas SL (1989). Role of receptor cycling in the regulation of angiotensin II surface receptor number and angiotensin II uptake in rat vascular smooth muscle cells. J ournal of Clinical Investigation, 84: 840-846.

6. Barak LS, Tiberi M, Freedman NJ , Kwatra MM, Lefkowitz RJ \& Caron MG (1994). A highy conserved tyrosine residue in $G$ protein-coupled receptors is required for agonist-mediated $\mathrm{B}_{2}$-adrenergic receptor sequestration. J ournal of Biological Chemis- try, 269: 2790-2795.

7. Hunyady L, Bor M, Baukal AJ , Balla $T \&$ Catt KJ (1995). A conserved NPLFY sequence contributes to agonist binding and signal for the type 1 angiotensin II receptor. J ournal of Biological Chemistry, 270: 16602-16609.

8. Thomas WG, Baker KM, Motel TJ \& Thekkumkara TJ (1995). Angiotensin II receptor endocytosis involves two distinct regions of the cytoplasmic tail. A role for residues on the hydrophobic face of a putative amphipathic helix. J ournal of Biological Chemistry, 270: 22153-22159.

9. Laporte SA, Servant G, Richard DE, Escher E, Guillemette G \& Leduc R (1996). The tyrosine within the NPYnY motif of 
the human angiotensin II type 1 receptor is involved in mediating signal transduction but is not essential for internalization. Molecular Pharmacology, 49: 89-95.

10. Chaki S, Guo DF, Yamano Y, Ohyama K, Tani M, Mizukoshi M, Shirai H \& Inagami $\mathrm{T}$ (1994). Role of carboxyl tail of rat angiotensin II type la receptor in agonist-induced internalization of receptor. Kidney International, 46: 1492-1495.

11. Balmforth AJ , Lee AJ , Balwinder PS, Bajaj CJ , Warburton P \& Ball SG (1995). Functional domains of the C-terminus of rat angiotensin $A T_{1 A}$ receptor. European J oumal of Pharmacology, 291: 135-141.

12. Hunyady L, Baukal AJ , Balla T \& Catt KJ (1994). Independence of type I angiotensin receptor endocytosis from $\mathrm{G}$ protein coupling and signal transduction. J ournal of Biological Chemistry, 269: 24798-24804.

13. Conchon S, Monnot B, Teutsch B, Corvol $P \&$ Clauser E (1994). Internalization of rat ATla and AT1b receptors: pharmacological and functional requirements. FEBS Letters, 349: 365-370.

14. Crozat A, Penhoat A \& Saez J (1996). Processing of angiotensin II (A-II) and [Sar $\left.{ }^{1}, \mathrm{Ala}^{8}\right]$-A-II by cultured bovine adrenocortical cells. Endocrinology, 118: 23122318.

15. Hunyady L, Tian $Y$, Sandberg K, Balla T \& Catt KJ (1994). Divergent conformational requirements for angiotensin II receptor internalization and signaling. Kidney International, 46: 1496-1498.

16. Goissis G, Nouailhetas VLA \& Paiva ACM (1976). Synthesis of biologically active retroenantiomers of angiotensin peptides. J ournal of Medicinal Chemistry, 19: 12871290.
17. Markwell M (1982). A new solid-state reagent to iodinate proteins. Analytical Biochemistry, 125: 147-154.

18. Roy SF, Laporte S, Echer E, Leduc R \& Guillemette G (1997). Epitope tagging and immunoreactivity of human angiotensin II type 1 receptor. Canadian J ournal of Physiology and Pharmacology, 75: 690-695.

19. Hjorth SA, Schambye H, Greenlee WG \& Schwartz TW (1994). Identification of peptide binding residues in the extracellular domains of the $A T_{1}$ receptor. J ournal of Biological Chemistry, 269: 30953-30959.

20. Sambrook J, Fritsch EF \& Maniatis T (1989). Molecular Cloning. A Laboratory Manual. Cold Spring Harbor Laboratory Press, Cold Spring Harbor.

21. Thomas WG, Motel TJ, Kule CE, Karoor V \& Baker KM (1998). Phosphorylation of angiotensin II (AT1A) receptor carboxyl terminus: a role in receptor endocytosis. Molecular Endocrinology, 12: 1513-1524.

22. Walker J KL, Premont RT, Barak LS, Caron MG \& Shetzline MA (1999). Properties of secretin receptor internalization differ from those of the $ß_{2}$-adrenergic receptor. J ournal of Biological Chemistry, 274: 31515-31523.

23. Tang $H$, Shirai $H \&$ Inagami $T$ (1995). Angiotensin II induces c-fos mRNA in aortic smooth muscle. Role of cell mobilization and protein kinase $\mathrm{C}$ activation. Circulation Research, 77: 239-248.

24. Miasiro N, Oshiro MEM, Paiva TB \& Paiva ACM (1983). Role of two N-terminal residues of angiotensin II in the production of tachyphylaxis. European J oumal of Pharmacology, 87: 397-406.

25. Hunyady L, Merelli F, Baukal AJ, Balla T \& Catt KJ (1991). Agonist-induced endocytosis and signal generation in adrenal glo- merulosa cells. A potential mechanism for receptor-operated calcium entry. J ournal of Biological Chemistry, 266: 2783-2788.

26. Schambye HT, Hjorth AS, Bergsma DJ Sathe G \& Schwartz TW (1994). Differentiation between binding sites for angiotensin II and nonpeptide antagonists on the angiotensin II type 1 receptors. Proceedings of the National Academy of Sciences, USA, 91: 7046-7050.

27. Hunyady L, Balla T \& Catt KJ (1996). The ligand binding site of the angiotensin AT1 receptor. Trends in Pharmacological Sciences, 17: 135-140.

28. Robertson AL \& Khairallah PA (1971). Angiotensin II: rapid localization in nuclei of smooth and cardiac muscle. Science, 172: 1138-1139.

29. Anderson KM \& Peach MJ (1994). Receptor binding and internalization of a unique biologically active angiotensin II-colloidal gold conjugate morphological analysis of angiotensin II processing in isolated vascular strips. J oumal of Vascular Research, 31: 10-17.

30. Tang SS, Rogg $\mathrm{H}$, Schumacher R \& Dzau VJ (1992). Characterization of nuclear angiotensin II binding sites in rat liver and comparison with plasma membrane receptors. Endocrinology, 131: 374-380.

31. Eggena $P$, Zhu J H, Clegg K \& Barrett J D (1993). Nuclear angiotensin receptors induce transcription of renin and angiotensinogen mRNA. Hypertension, 22: 496501.

32. Kiron MA \& Soffer RL (1989). Purification and properties of a soluble angiotensin II binding protein from rabbit liver. J ournal of Biological Chemistry, 264: 4138-4142. 